\title{
Application of MBNQA for service quality management and performance in healthcare organizations
}

\author{
Sunil C. D'Souza ${ }^{1}$, A.H. Sequeira ${ }^{2}$ \\ 1 * Department of Humanities, Social Sciences and Management, National Institute of Technology Karnataka, INDIA \\ 2 Department of Humanities, Social Sciences and Management, National Institute of Technology Karnataka, INDIA \\ *Corresponding Author: Email: sunildsouza31@gmail.com ,Tel + 91-9886414835, Fax.0824-2474033
}

\begin{abstract}
The aim of this research is to examine the relationship between service quality management dimensions (quality management and patient service quality) and their impact on performance of the healthcare organizations. The organizations that deliver service must broaden their examination of quality from the conventional organization-oriented perspective to a dual, organization customer perspective. The quantitative methodology was employed to test model of service quality management and performance through an integrated perspective. The MBNQA (Malcolm Baldrige National Quality Award) criteria and grounded theory for patient service quality was adopted to measure the internal and external service quality of healthcare organizations. Further, the study aligned the internal and external service quality to obtain the holistic view of service quality management and performance in healthcare organizations from the perspective of internal and external customers. The outcome of the study indicated that the healthcare organizations had a silver line performance based on MBNQA criteria. Overall, the study reinforced service quality management and performance with the application of MBNQA criteria in healthcare organizations.
\end{abstract}

Keywords: MBNQA (Malcolm Baldrige National Quality Award) criteria, service quality, performance, and healthcare organization

\section{DOI: http://dx.doi.org/10.4314/ijest.v3i7.6S}

\section{Introduction}

Global health is the health of populations in a global context and transcends the perspectives and concerns of Individual nations (Brown et al. 2006). Globalization and liberalisation policies have significantly changed the healthcare scenario of India. In the recent years, there is an increasing need for quality performance in healthcare organizations (Kunal et al.2005). The Indian healthcare industry is worth Rs. 8, 20,000 million today with global revenues of approximately US \$2.8 trillion. The healthcare industry is world's largest industry and India is emerging as a major player because of its high population (D.M.Pestonjee et al.2005). The Union Budget 2002-2003 conferred infrastructure status on the healthcare industry under Section 10(23G) of the Income Tax Act. This provides the opportunity for the hospitals to raise long-term capital. As hospitals in India are not only growing in number, but also in size, complexity, and the types of the services provided, there is growing need for service quality. The concept of service quality in healthcare organizations needs to be explored in the context of changing quality dimensions. There is a need to identify their scope in service quality research with the changing issues of dimensionality, to adopt suitable dimensions for performance improvement and further it emphasizes the need for a holistic framework for measuring performance in healthcare organizations. This issue is significant because of concurrent view amongst various researchers in service management that there are both hard and soft issues reflecting, the lack of strategic thinking and goal clarity, necessitating a measurement system that focuses on application of a comprehensive measurement system in service organizations especially in healthcare (D'Souza Sunil and Sequeira A.H, 2010a). Social and economic changes are also demanding for high healthcare service quality. Organisations are beginning to recognise that quality is need for survival. Services are not meeting expectations because they are falling short of their potential to improve quality and performance outcomes. Organizations that deliver service must 
broaden their examination of quality from the conventional organization-oriented perspective to a dual, organization - customer perspective.

With increasing awareness, the patients, as consumers expect quality in healthcare services. The Indian healthcare providers are also significant players in the international market making India a preferred 'health and medical tourism destination.' With new terms such as health tourism, healthcare outsourcing, and medical back office support being bandied about, given right mix of government push and private sector initiative, India could emerge as a cost-effective healthcare service provider in Asia and indeed to the rest of the world. The changes such as mature markets, alternatives of delivery systems, competitive health plans, powerful coalitions, increasing knowledgeable consumers and technology are demanding from service providers and patients a better understanding of service quality. The productivity of the healthcare organization also depends on strategic blend of hospital information system, alliances, partnerships, telemedicine and networking, are shared, pooled and integrated to provide quality healthcare services (D'Souza and Sequeira, 2008). Policy makers and public have a legitimate interest in wide range of aspects of performance, such as efficiency, the quality of the healthcare process, accessibility, clinical outcomes and responsiveness (Institute of Medicine, 2001). There is also increasing pressure from competitors, governments and regulatory bodies to constantly improve performance, quality, safety and access and drive organizational excellence (Microsoft, 2008). Also, the industry being service driven, many of the current performance management tools and methods which work well in other industries may not be directly applicable to the healthcare industry. Performance management in health systems becomes more difficult due to several factors including the lack of effective methods for enhancing performance, lack of leadership, accountability and line management as well as poor strategic planning. An appropriate model for managing performance in the healthcare industry should be flexible, adaptable and responsive to changes in the healthcare industry. There is a need for strategic determinants to improve service quality and performance, and to develop as performance excellence strategies. These strategies will promote continuous performance improvement in quantity, quality and equity of service provision.

\section{Review of Related Literature}

The principal methods of measuring hospital performance are regulatory inspection, public satisfaction surveys, third-party assessment and statistical indicators (Shaw, 2003). There are growing demands to ensure transparency, control and reduce variations in clinical practice (Groene et al. 2008). Without maintaining a standard level of care, the reputation of the hospital can be in jeopardy (Hibbared et al. 2005). Gauging performance can allow hospital governing boards to recognize areas of improvement (Griffith et al. 2002). Dashboard metrics and report cards have emerged as viable options for evaluation of healthcare programmes and managerial practices (Woodward et al. 2004). Indicators need to be translated into generaliazable, standardized, interpretable and useable information for clinicians or service managers in the form of performance measurement tools (Willis et al. 2008). Several performance management tools for hospitals have been created to assist in this process (Ruiz and Simon, 2004). Quality management had significant impact on the approach to management in Western economies since its promotion concept in US in 1980s (Andersen et al. 2004). In 2001, more than 800,000 copies of Malcolm Baldrige National Quality Award criteria (MBNQA) ${ }^{1}$ were distributed in the USA and the British Quality Foundation estimates that more than 20,000 organisations across Europe are using the European Foundation for quality management(EFQM) model and that the number is rising(Andersen et al. 2004). Balance Score Card (BSC) involves all tiers of the organization whereas using the quality management system may result in less emphasis at higher organization levels (Ovretveit and Al Serouri, 2006).

Quality Management (QM) theory has developed from three sources, contributions from quality gurus (Deming, 1982; Juran, 1988), formal assessment processes (EFQM, MBNQA, and Deming prize), and measurement studies (Saraph et al. 1989). QM theory has identified several QM dimensions that may be used to measure the QM levels in the context of performance. Such dimensions have been documented and analysed empirically in measurement studies, as well as in studies that explored the relationship between $\mathrm{QM}$ and performance. The document analysis indentified that there was a changing role of quality dimensions of MBNQA from 1988 to 2008 in approximately 5-years intervals that is 1988, 1992, 1997, 2003 and 2008 of the reports of US Department of Commerce National Institute of Standards and Technology (D'Souza and Sequeira, 2010b). It is evident from the studies that most of the QM dimensions have described as: (i) People Management (involvement and training); (ii) Information and Analysis (quality data, measurement, process control, feedback and benchmarking); (iii) Customer Focus (customer relationships); (iv) Leadership (top management commitment); (v) Process Management (service delivery and improvement); (vi) Supplier Management (relational practices associated with suppliers); (vii) Planning (definition, communication and review of objectives and plans); and (viii) Product Design (departments involvement in design reviews, clarity of specifications and emphasis on quality). Therefore, it has too many dimensions to be fitted and certainly very difficult to approach the measurement of the performance based on issues of dimensionality (Table 1).

\footnotetext{
${ }^{1}$ Name after former U. S. secretary of commerce, the late Malcolm Baldrige
} 
Table 1. Brief Summary of QM Dimensions

\begin{tabular}{|c|c|c|c|c|c|c|c|c|c|c|c|c|c|c|c|}
\hline QM dimension & 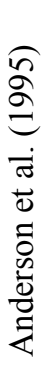 & 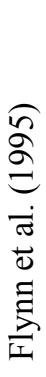 & 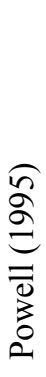 & 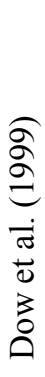 & 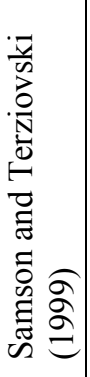 & 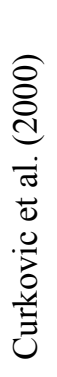 & 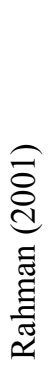 & 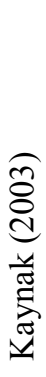 & 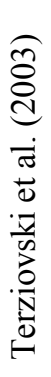 & 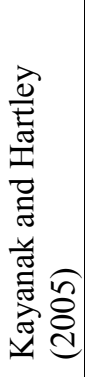 & 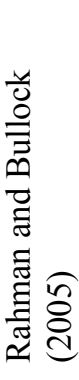 & 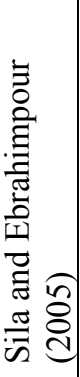 & 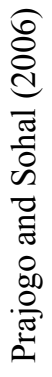 & 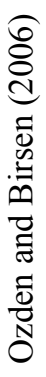 & 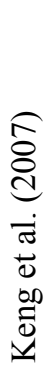 \\
\hline $\begin{array}{l}\text { People } \\
\text { management }\end{array}$ & $\mathrm{x}$ & $\mathrm{x}$ & $\mathrm{x}$ & $\mathrm{x}$ & $\mathrm{X}$ & $\mathrm{x}$ & $\mathrm{x}$ & $\mathrm{x}$ & & $\mathrm{x}$ & $\mathrm{x}$ & $\mathrm{x}$ & $\mathrm{x}$ & $\mathrm{x}$ & $\mathrm{x}$ \\
\hline $\begin{array}{l}\text { Information and } \\
\text { analysis }\end{array}$ & $\mathrm{X}$ & $\mathrm{X}$ & $\mathrm{X}$ & $\mathrm{X}$ & $\mathrm{X}$ & $\mathrm{X}$ & $\mathrm{X}$ & $\mathrm{X}$ & $\mathrm{X}$ & $\mathrm{X}$ & $\mathrm{X}$ & $\mathrm{X}$ & $\mathrm{X}$ & & $\mathrm{X}$ \\
\hline Customer focus & $\mathrm{x}$ & $\mathrm{x}$ & $\mathrm{x}$ & & $\mathrm{X}$ & $\mathrm{x}$ & $\mathrm{x}$ & & $\mathrm{x}$ & $\mathrm{x}$ & $\mathrm{x}$ & $\mathrm{x}$ & $\mathrm{x}$ & $X$ & $\mathrm{X}$ \\
\hline Leadership & $\mathrm{x}$ & $\mathrm{x}$ & $\mathrm{x}$ & & $\mathrm{X}$ & & $\mathrm{x}$ & $\mathrm{x}$ & & $\mathrm{x}$ & & $\mathrm{X}$ & $\mathrm{x}$ & $X$ & $X$ \\
\hline $\begin{array}{l}\text { Process } \\
\text { Management }\end{array}$ & $\mathrm{x}$ & $\mathrm{x}$ & $\mathrm{X}$ & & $\mathrm{X}$ & & $\mathrm{x}$ & $\mathrm{x}$ & & $\mathrm{X}$ & & $\mathrm{X}$ & $\mathrm{X}$ & & \\
\hline $\begin{array}{l}\text { Supplier } \\
\text { management }\end{array}$ & & $\mathrm{x}$ & $\mathrm{x}$ & $\mathrm{x}$ & & $\mathrm{x}$ & & $\mathrm{x}$ & & $\mathrm{x}$ & $\mathrm{x}$ & $\mathrm{x}$ & & & \\
\hline Planning & & & & $\mathrm{X}$ & $\mathrm{X}$ & & $\mathrm{x}$ & $\mathrm{X}$ & & & $\mathrm{x}$ & $\mathrm{X}$ & $\mathrm{X}$ & & \\
\hline Product design & & $\mathrm{x}$ & & & & & $\mathrm{x}$ & $\mathrm{x}$ & & $\mathrm{x}$ & & & & & \\
\hline
\end{tabular}

A review of past empirical studies on Organizational performance indicates that there are variations in measuring performance of organisations (Monge et al. 2006). Different variables used for measuring Organizational performance have been identified from the literature as shown in Table 2.

Table 2. Performance Measures Proposed by Key Researchers

\begin{tabular}{|l|l|l|}
\hline Variables & Measure & Key Researchers \\
\hline $\begin{array}{l}\text { Satisfaction level } \\
\text { Business results }\end{array}$ & Organizational performance & Lin et al.(2005) \\
\hline $\begin{array}{l}\text { Quality performance } \\
\text { Innovation performance }\end{array}$ & Organizational performance & $\begin{array}{l}\text { Prajogo and } \\
\text { Sohal (2004) }\end{array}$ \\
\hline $\begin{array}{l}\text { Organizational effectiveness } \\
\text { Financial results } \\
\text { Market results }\end{array}$ & Performance & Sila(2007) \\
\hline $\begin{array}{l}\text { Financial performance } \\
\text { Operational performance } \\
\text { Product quality }\end{array}$ & Organizational performance & Lakhal et al.(2006) \\
\hline
\end{tabular}

The MBNQA has been accepted widely as service excellence standard, measured along the lines of leadership, strategic planning, customer and market focus, informational analysis, human resources, process management like those in education and healthcare institutions (Chow and Goh, 2000). The Information system is the newest dimension among the MBNQA criteria (US DoCNBS, 2003). The Information system performance was assessed in terms of management relevant data and information. The results intended for the quality performance improvement in relation to Measurement, Analysis and Knowledge Management in healthcare organizations (D'Souza Sunil and Sequeira A.H, 2011). The process management dimension is re named as operations focus to address the special focus on operational efficiency of organisation (US DoCNBS, 2011). 
However, there is a need of applying the International recognized organizational excellence standard (MBNQA) in the context of healthcare organizations in India. The MBNQA criteria provide a system perspective to achieve the organizational performance excellence and to overcome the issues of healthcare quality measures. The first six dimensions of MBNQA are quality management includes leadership; strategic planning; customer focus; measurement, analysis, and knowledge management; workforce focus; and process management. The seventh dimension is results or the performance which includes healthcare outcomes, customer -focused outcomes, financial and market outcomes, workforce -focused outcomes, process effectiveness outcomes, and leadership outcomes (US DoCNBS, 2008).

Table. 3 MBNQA Criteria -2009-2010

\begin{tabular}{|c|l|c|}
\hline Sl. No. & \multicolumn{1}{|c|}{ Category (variables) } & Category points \\
\hline 1 & Leadership & 120 \\
\hline 2 & Strategic planning & 85 \\
\hline 3 & Customer focus & 85 \\
\hline 4 & Measurement, analysis, and knowledge management & 90 \\
\hline 5 & Workforce focus & 85 \\
\hline 6 & Process management & 85 \\
\hline 7 & Results (Performance outcomes) & 450 \\
\hline & Total points & 1,000 \\
\hline
\end{tabular}

Source: US Department of Commerce National Institute of Standards and Technology

The high quality healthcare which is expected to maximise patient welfare, after one has taken into account balancing expected gains and losses that accompany the process of care in all aspects (Donabedian,1980). The quality in a healthcare organization is three dimensional: patient quality is what patients say they want; professional quality is what professional think patients need (outcome and process); and management quality is the fewest resources to give patients what they want and need, without waste, errors or delay, and within the policy and legal regulation(Overetveit,2000). Therefore, Patient perceived quality is the overall service quality of healthcare organization. There is a need of interlinking internal measure of service quality and external measure of service quality ( $\mathrm{Li}, 1997)$. Focusing on one aspect of an organisation's performance fails to provide a systemic view of the performance of a healthcare organization. Monitoring and evaluation gives meaning to the accountability of relationships between clients, policy makers and providers (M. Pilani et al.2007). Work to develop sensitive and easily measurable indicators for monitoring changes within each health system building block is ongoing (WHO, 2009). Such tools are necessary if systems are capable of achieving the effective and universal coverage at sufficient quality and safety necessary for improved health and health equity, responsiveness, risk protection and efficiency (WHO, 2009). The core value of the MBNQA is consistent with organisation development and management, as it offers the relationship between quality management and performance. There is a research gap that the MBNQA criteria need to be used in assessing quality management and performance in Indian healthcare organizations. The MBNQA criteria are proposed to be the foundation of Quality management in healthcare organizations, studied in medical college hospitals to determine if the relationship proposed by the MBNQA criteria exists in the market place. There is no published empirical evidence that the performance relationship proposed by the MBNQA criteria exists in healthcare orgainsations with levels of quality performance in India. Excellent service quality generates a competitive advantage for service organisations, but firms must implement a comprehensive system of quality management if they are to develop effective and reliable service quality (Yang Ching, 2006). Measuring service quality is multidimensional and there is a need to integrate the Quality Management dimensions (QMDs) of MBNQA (internal service quality) and Patient Service Quality dimensions (PSQDs) (external service quality) and their impact on performance.

Research questions

1. Is there any relationship between quality management dimensions of MBNQA and performance?

2. Is there any relationship between patient service quality and performance?

3. How to evaluate the performance of the healthcare organizations? 


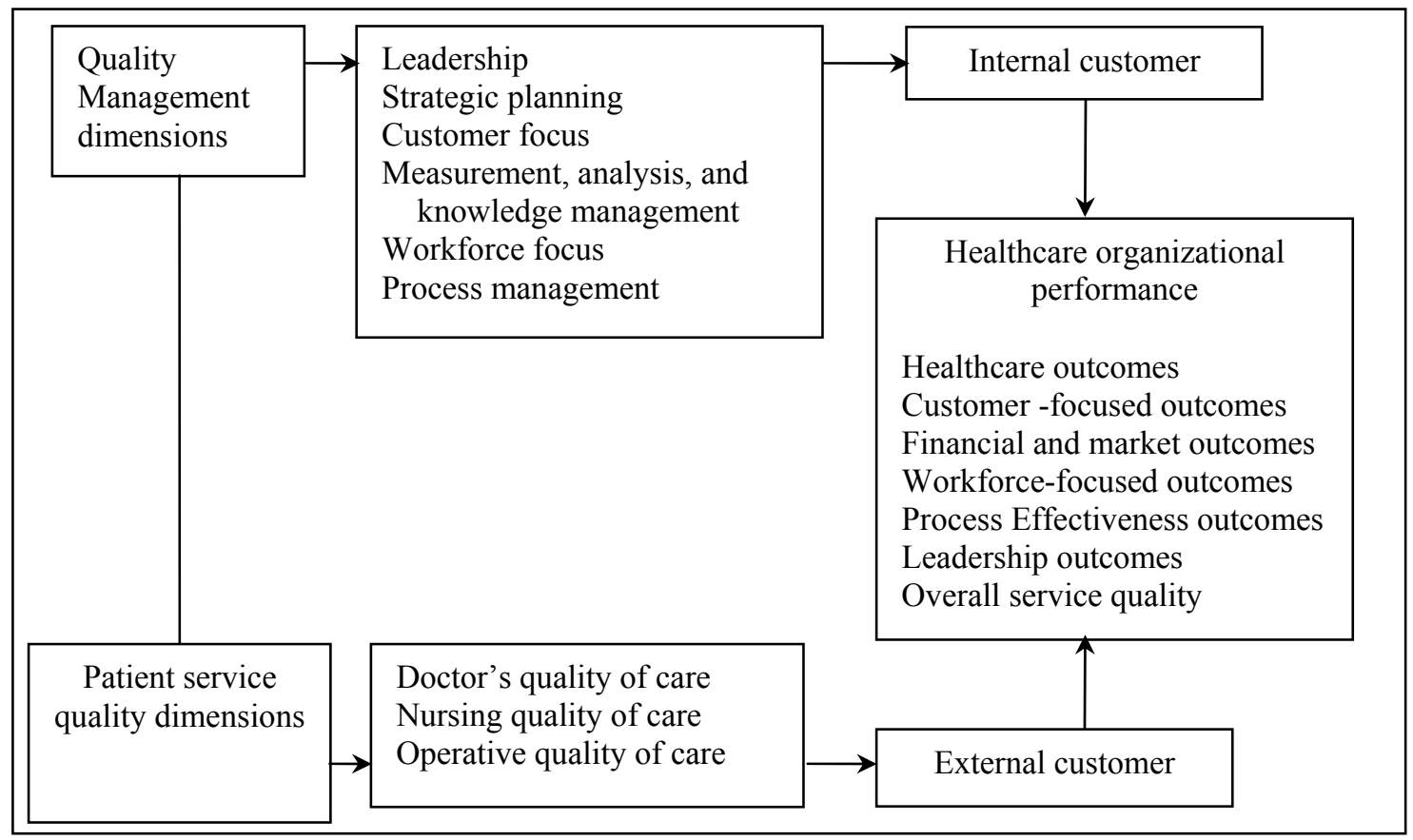

Figure 1. The Research Framework: Service Quality dimensions and Performance in Healthcare organizations

\section{Research Methodology}

The case study design used both deductive and inductive approaches. The deductive approach used self-administered questionnaire for MBNQA framework and patient perceived quality. Inductive approach conducted the unit analysis of healthcare organizations and grounded theory for patient service quality. The case study design is focused on the study of service quality dimensions and performance in healthcare organizations from internal and external customer through integrated perspective.

\subsection{Population and Sampling}

In order to achieve the objectives of the study, the hospitals affiliated to medical colleges of southern India were considered as the population of this study. The population consisted of 76 medical college hospitals (healthcare organizations) and the sample survey was derived from the database of healthcare organizations prepared based on official report of Medical Council of India in 2009 , and it was found majority of medical colleges hospitals(38\%) were concentrated in southern India. One of the healthcare organizations was selected for the unit analysis to obtain an overall glimpse of administration, operations, standards and practices as it is uniform under the Medical Council of India. To obtain clear representation of samples from southern India, healthcare organizations of Karnataka, Kerala, Andhra Pradesh and Tamil Nadu were purposively selected based on inclusion and exclusion criteria for this study. The study was designed with cooperation from 12 healthcare organizations. Among the 12 participating healthcare organizations, 7 were private $(58.33 \%), 2$ were public $(16.66 \%)$, and 3 were charitable $(25 \%)$ based on their ownership.

Inclusion criteria includes large healthcare organization more than 500 beds, quality certified, multi-specialty, minimum five years of existence, emergency department, should have a divisional / state representation. Exclusion criteria includes small healthcare organization less than 500 beds, single specialty, super specialty, and less than five years of existence. Purposive sampling technique was used taking into consideration the respondent's availability, willingness to share information and location of healthcare organizations. The pilot study results were also used to project the approximate sample size. By using purposive sampling technique 130 administrative executives and 1200 patients were selected. The influence of sample size on the variability of factor loadings is critical as the magnitude of factor loadings is used as a criterion to determine which variables are substantially related to a given factor and thus should be included in the interpretation of a factor (Comrey and Lee, 1973).

\subsection{Measures and Reliability}

In order to obtain content validity, this research followed the recommended procedures of Cooper and Schindler (2001) through identifying the existing scales from the literature and conducting interviews with panel of experts (including academicians and practitioners from the industry), asking them to give their comments on the research tools used. The expert team members for the content validity consisted of hospital administrators, senior doctors, senior nurses, senior paramedical staff, and professors in hospital administration and business administration. The instrument developed for this study comprised nine independent variables 
and two dependent variables. The instrument developed with a five-point Likert scale $(1-$ strongly disagree and 5 - strongly agree). Prior to the full survey, a pilot study was administered to 20 managers of one of the healthcare organizations of South India. The goal of the pilot study was to examine the content validity of the questionnaire and getting feedback concerning technical issues associated with the questionnaire including its structure and length, clarity of the statements and terminologies used, and its layout and presentation. A total of 12 responses were received, and none of the respondents indicated serious difficulties in completing the questionnaire pertaining to the clarity of the content and time for completing the questionnaire. Independent variable measures were leadership; strategic planning; customer focus; measurement, analysis, and knowledge management (MAK); workforce focus; process management; and dependent variable measures were includes healthcare outcomes, customer focused outcomes, financial and market outcomes, workforce -focused outcomes, process effectiveness outcomes, and leadership outcomes for MBNQA dimensions. Independent variable measures of patient perceived quality includes doctors care of quality, nursing care of quality, and operative care of quality and dependent variable measure is overall service quality. The reliability analysis through calculating the Cronbach's Alpha revealed that the values surpassed the threshold of 0.7 as suggested by Nunnally (1978). A total of 150 scale items were used to measure the constructs in the research framework. The grounded theory was developed for patient service quality and the unit analysis of healthcare organizations was also conducted. In conformity with the ethical requirements of healthcare organizations, formal consents for conducting research were obtained. Descriptive and inferential statistics was applied using SPSS (Statistical Package for the Social Sciences).

\section{Results and Discussions}

The reliability was obtained by computing Cronbach Alpha that measures the internal consistency of the items. Owing to multidimensionality of Service Quality management, Cronbach Alpha was computed separately and it was ranged from 0.7 to 0.9, indicating higher level of internal consistency.

Table 4. Reliability Analysis- Service Quality dimensions and Performance

\begin{tabular}{|l|c|c|}
\hline Dimensions & No. of Items & Cronbach Alpha \\
\hline Leadership & 18 & 0.849 \\
\hline Strategic planning & 10 & 0.951 \\
\hline Customer focus & 14 & 0.831 \\
\hline Measurement, Analysis, and Knowledge management & 17 & 0.916 \\
\hline Workforce focus & 22 & 0.951 \\
\hline Process management & 16 & 0.943 \\
\hline Doctor quality of care & 10 & 0.807 \\
\hline Nursing quality of care & 10 & 0.689 \\
\hline Operative quality of care & 10 & 0.690 \\
\hline Results (performance outcomes) & 18 & 0.882 \\
\hline overall service quality & 5 & 0.683 \\
\hline
\end{tabular}

4.1 Is there any relationship between quality management dimensions of MBNQA and performance?

To address this research question, correlation analysis is presented in the Table 5, indicated the significant relationship between quality management dimensions and performance of MBNQA model $(\mathrm{p}<0.001)$. The very high significant correlation was found between 'strategic planning' $(r=0.766, \mathrm{P}<0.001)$, 'process management' $(\mathrm{r}=0.765, \mathrm{P}<0.001)$ with the 'performance'. The correlation ranked highest for 'process management,' second for 'strategic planning,' third for 'workforce focus,' fourth for 'measurement, analysis and knowledge management,' fifth for 'leadership,' and sixth for 'customer focus on performance.' There was also an inter-group correlation between MBNQA dimensions and MBNQA dimensions were significantly correlated with each other $(\mathrm{p}<0.001)$ (an Exhaustive list of these items found in Appendix 1). 
Table 5. Pearson Correlation Matrix of MBNQA Dimensions

\begin{tabular}{|c|c|c|c|c|c|c|c|}
\hline & & Leadership & $\begin{array}{l}\text { Strategic } \\
\text { planning }\end{array}$ & $\begin{array}{l}\text { Customer } \\
\text { focus }\end{array}$ & $\begin{array}{l}\text { Measurement, } \\
\text { analysis and } \\
\text { knowledge } \\
\text { management }\end{array}$ & $\begin{array}{l}\text { Work-force } \\
\text { focus }\end{array}$ & $\begin{array}{c}\text { Process } \\
\text { management }\end{array}$ \\
\hline \multirow[t]{2}{*}{ Performance } & $\mathrm{r}$ & 0.593 & 0.766 & 0.479 & 0.638 & 0.671 & 0.765 \\
\hline & $\mathrm{p}$ & 0.001 & 0.001 & 0.001 & 0.001 & 0.001 & 0.001 \\
\hline \multirow[t]{2}{*}{ Leadership } & $\mathrm{r}$ & & 0.665 & 0.604 & 0.735 & 0.659 & 0.659 \\
\hline & $\mathrm{p}$ & & 0.001 & 0.001 & 0.001 & 0.001 & 0.001 \\
\hline \multirow[t]{2}{*}{ Strategic planning } & $\mathrm{r}$ & & & 0.503 & 0.671 & 0.697 & 0.753 \\
\hline & $\mathrm{p}$ & & & 0.001 & 0.001 & 0.001 & 0.001 \\
\hline \multirow[t]{2}{*}{ Customer focus } & $\mathrm{r}$ & & & & 0.780 & 0.657 & 0.604 \\
\hline & $\mathrm{p}$ & & & & 0.001 & 0.001 & 0.001 \\
\hline \multirow{2}{*}{$\begin{array}{l}\text { Measurement, analysis \& } \\
\text { knowledge management }\end{array}$} & $\mathrm{r}$ & & & & & 0.847 & 8.140 \\
\hline & $\mathrm{p}$ & & & & & 0.001 & 0.001 \\
\hline \multirow[t]{2}{*}{ Workforce focus } & $\mathrm{r}$ & & & & & & 0.811 \\
\hline & $\mathrm{p}$ & & & & & & 0.001 \\
\hline
\end{tabular}

\subsection{Is there any relationship between patient service quality and performance?}

To address this research question, grounded theory was developed for patient service quality. Patient service quality was open coded as, doctors' quality of care,' 'nursing quality of care,' and 'operative quality of care.' The highest positive correlation found in the operational quality of care on performance $(\mathrm{r}=0.329, \mathrm{p}=0.000)$. The nursing quality of care and doctor quality of care had lowest positive correlation on performance $(\mathrm{r}=0.194, \mathrm{p}=0.000 ; \mathrm{r}=0.203, \mathrm{p}=0.000)$. There was also a significant inter group correlation between patient service quality factors and performance $(\mathrm{p}=0.000)$ and patient service quality factors significantly influenced the performance (Appendix II).

\subsection{How to evaluate the performance of the healthcare organizations?}

There were a significant number of healthcare organizations that had a silver line performance based on MBNQA points $(83.33 \%)$. Among the participant healthcare organizations, HCO5 had highest (664.8 points) MBNQA points and HCO6 had the lowest (442 points). Total MBNQA points of the healthcare organizations strongly imply the need of adopting the MBNQA dimensions.

Table 6. Summary of Performance Evaluation

\begin{tabular}{|l|l|l|c|c|}
\hline \multicolumn{1}{|c|}{ Range } & Performance Level & Healthcare Organizations (HCOs) & Total Number & \% \\
\hline $\mathbf{1 0 0 0 - 7 5 0}$ & Golden & None & 0 & 0.00 \\
\hline $\mathbf{7 5 0 - 5 0 0}$ & Silver & $\begin{array}{l}\text { HCO1, HCO2, HCO5, HCO9, HCO10, HCO12, } \\
\text { HCO3, HCO7, HCO8, HCO11 }\end{array}$ & 10 & 83.33 \\
\hline$>\mathbf{5 0 0}$ & Bronze & HCO4, HCO6 & 2 & 16.67 \\
\hline
\end{tabular}

4.4Factor analysis results of MBNQA Dimensions

The factor analysis was applied to analyse quality management dimensions of MBNQA with varimax rotation. The 6 factors were identified for leadership: (i) Service Leadership, (ii) Departmental Quality Management Leadership, (iii) Governance and Social Responsibility, (iv) Top management Commitment to Quality Improvement, (v)Participative Leadership,(vi) Corporate Social Responsibility. Leadership had significant correlation with the Performance $\left(\mathrm{H}_{1}: \mathrm{t}=8.330, \mathrm{p}<0.001, \mathrm{r}=0.593\right)$. The 1 factor was identified for Strategic planning i.e. Strategic deployment. Strategic planning had significant correlation with Performance $\left(\mathrm{H}_{2}: \mathrm{t}=13.48, \mathrm{p}<0.001, \mathrm{r}=0.766\right)$. The 5 factors were identified for Customer Focus:(i)Customer Feed Back, (ii)Customer Orientation,(iii) Customer patronization, (iv)Voice of Customer and (v) Benchmarking. Customer focus had significant correlation with Performance $\left(\mathrm{H}_{3}: \mathrm{t}=6.38, \mathrm{p}<0.001, \mathrm{r}=0.479\right)$. The 3 factors were identified for Measurement, Analysis, and Knowledge Management: (i) Technology and Performance System, (ii) Daily Information Analysis and (iii) Integration of Data Base Management. Measurement, analysis and knowledge management had significant correlation with 
Performance $\left(\mathrm{H}_{4}: \mathrm{t}=9.02, \mathrm{p}<0.001, \mathrm{r}=0.638\right)$. The 5 factors were identified for Workforce focus:(i)Empowerment, (ii) Human Resource Policy, (iii) Employee Involvement, (iv) Training and Development, and Working Environment. Workforce focus had significant correlation with the Performance, $\left(\mathrm{H}_{5}: \mathrm{t}=9.9, \mathrm{p}<0.001, \mathrm{r}=0.671\right)$. The 2 factors were identified for Process management: (i) Service Delivery and Control, and (ii) Customer Participation in Service Delivery. Process management had significant correlation with the Performance $\left(\mathrm{H}_{6}: \mathrm{t}=13.43, \mathrm{p}<0.001, \mathrm{r}=0.659\right)$. The factor analysis emphasized that the quality management dimensions of MBNQA were important and found to be significant with the performance.

\subsection{Performance/Results}

The document analysis of healthcare organizations was conducted based on 'results dimension' of MBNQA presented in Table 7.

Table 7. Healthcare Organizations -Performance: March, 2009

\begin{tabular}{|l|c|}
\hline Average number of beds & 1071 \\
\hline Average Annual Turnover & 1900.08 million \\
\hline Average Out Patient Admissions & 0.29 million \\
\hline Average In Patient Admissions & 0.07 million \\
\hline Average Radio Diagnosis & 2416 \\
\hline Average General Surgeries & 2220 \\
\hline Average number Delivery Cases & 1595 \\
\hline General Mortality rate & $4.15(\%)$ \\
\hline Average number Foreign Patients & 86 \\
\hline Average Employee turnover & $12.41(\%)$ \\
\hline Number of resident doctors & 183 \\
\hline Average number of Administrative staff & 185 \\
\hline Average Occupancy rate & $73(\%)$ \\
\hline Average Campus Size & $70.48($ Acres $)$ \\
\hline Average number years in service & 47 \\
\hline Average number Employees & 2500 \\
\hline
\end{tabular}

\subsection{Model of MBNQA Dimensions}

With regard to the MBNQA dimensions, strategic planning had a significantly very high strong positive relationship ( $\beta=0.766$ for $\left.\mathrm{H}_{2}\right)$ than process management $\left(\beta=0.765\right.$ for $\left.\mathrm{H}_{6}\right)$, workforce $\left(\beta=0.661\right.$ for $\left.\mathrm{H}_{5}\right)$, measurement, analysis, and knowledge management $\left(\beta=0.624\right.$ for $\left.\mathrm{H}_{4}\right)$, leadership $\left(\beta=0.593\right.$ for $\left.\mathrm{H}_{1}\right)$, and customer focus $\left(\beta=0.491, \mathrm{P}=0.000\right.$ for $\mathrm{H}_{3}$ ) on performance (Figure 2). 


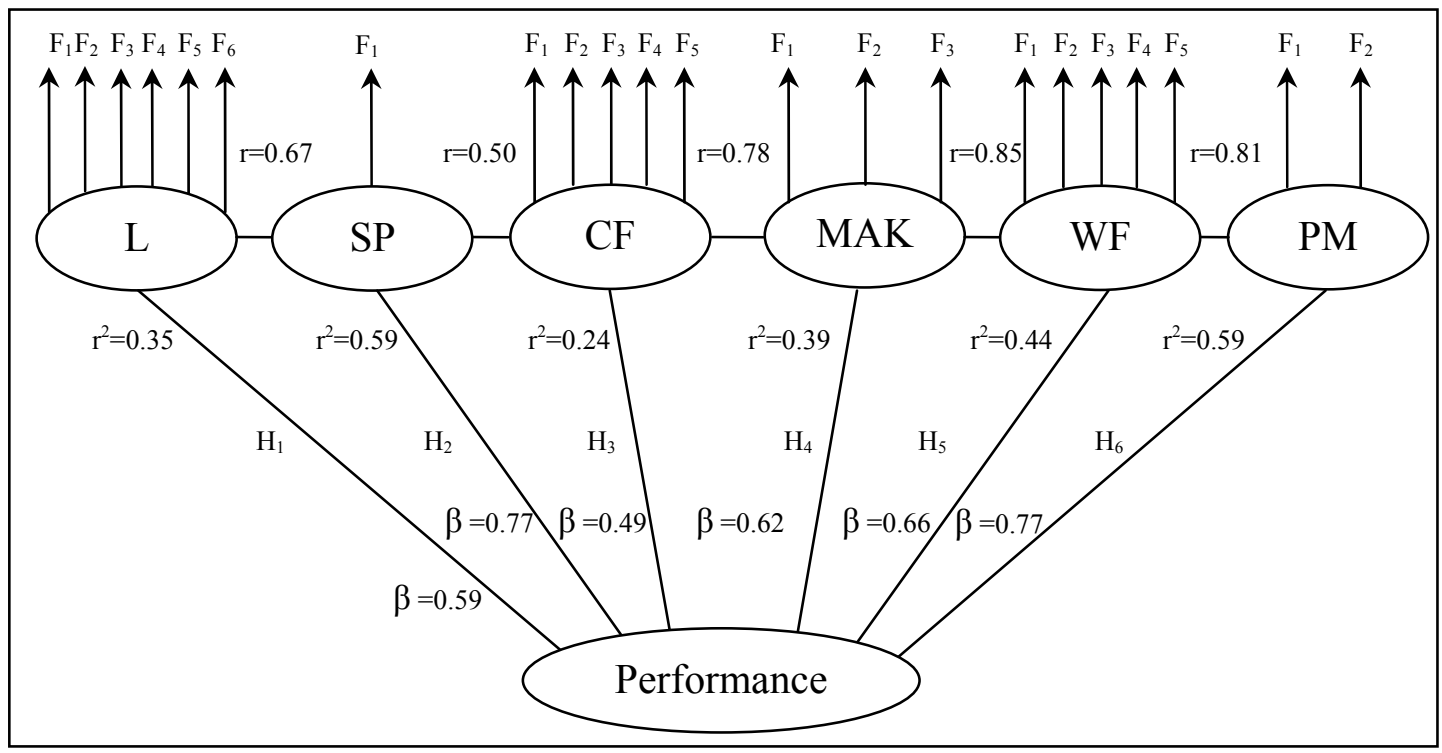

Figure 2. Measurement Model of MBNQA Dimensions

Note: $\mathrm{L}=$ Leadership, $\mathrm{SP}=$ Strategic planning, $\mathrm{CF}=$ Customer focus, $\mathrm{MAK}=$ Measurement analysis and knowledge management, $\mathrm{WF}=$ Workforce focus, $\mathrm{PM}=$ Process Management. $\beta=$ regression coefficient, $\mathrm{r}=$ Pearson Correlation coefficient, Significant at $\mathrm{P}=0.000$

\subsection{Model of Patient Service Quality}

The operative quality of care had significantly high strong positive relationship $\left(\beta=0.279 \mathrm{for}_{9}\right)$ on performance than doctor quality of care $\left(\beta=0.065\right.$ for $\left.\mathrm{H}_{7}\right)$, nursing quality of care $\left(\beta=0.053\right.$ for $\left.\mathrm{H}_{8}\right)$ (Figure 3 ).

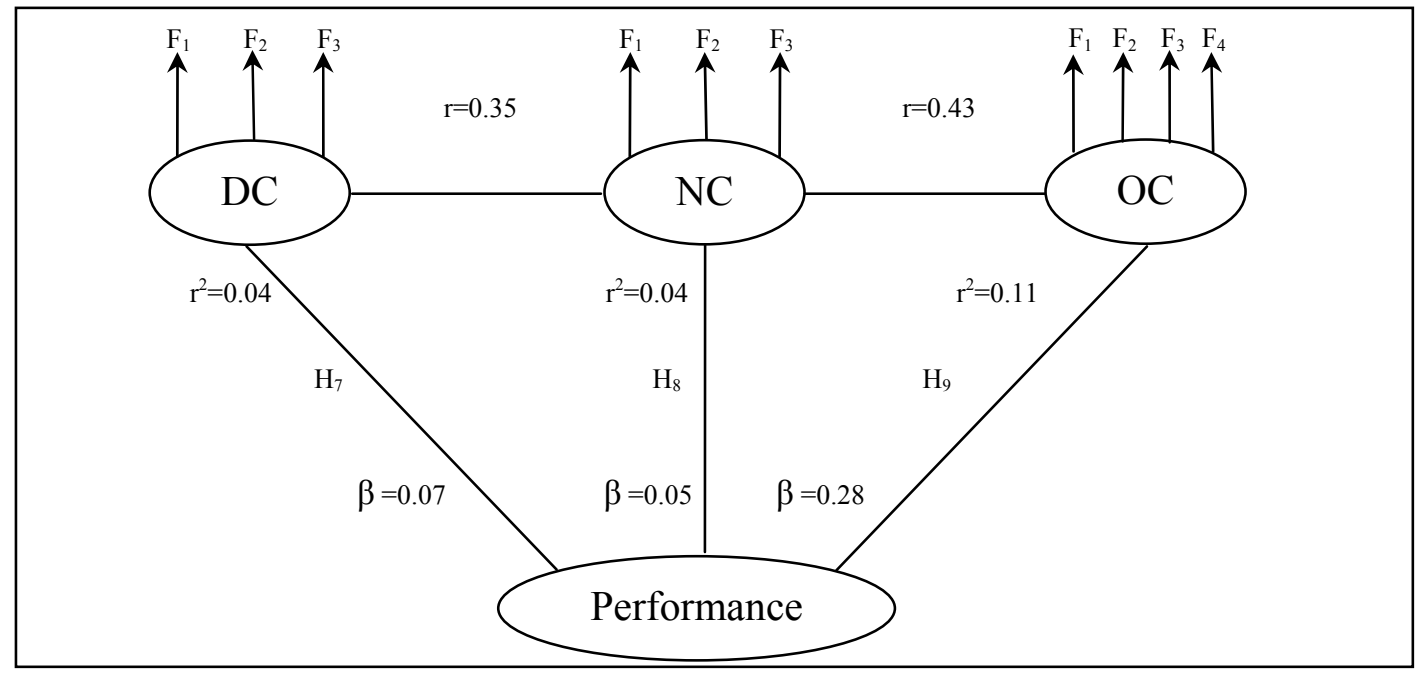

Figure 3. Measurement model of Patient Service Quality

Note: DC- Doctor quality of care, NC- Nursing quality of care, OC- Operational quality of care. $\beta=$ regression coefficient, $r=$ Pearson correlation coefficient, Significant at $\mathrm{P}=0.000$

\subsection{Service Quality management and Performance in Healthcare organizations}

QM dimensions (leadership, strategic planning, customer focus, measurement, analysis, and knowledge management, workforce focus, and process management) yielded $58.5 \%$ explanatory power on performance. Patient service quality (doctor quality of care, nursing quality of care and operative quality of care) yielded $11.2 \%$ explanatory power on performance (Table 8 ). The hypotheses $\mathrm{Hqm}$ and Hps were statically significant $(\mathrm{P}<0.001)$. The service quality dimensions influenced the performance of the healthcare organizations (Table 9). 
Table 8. Model Summary - Service Quality dimensions and Performance

\begin{tabular}{|c|c|c|c|c|c|}
\hline Model & $\mathbf{R}$ & R Square & $\begin{array}{l}\text { Adjusted R } \\
\text { Square }\end{array}$ & $\begin{array}{c}\text { Std. Error of the } \\
\text { estimate }\end{array}$ & Beta $(\beta)$ \\
\hline Quality Management & 0.767 & 0.589 & 0.585 & 0.36156 & 0.767 \\
\hline Patient Service Quality & 0.339 & 0.115 & 0.112 & 0.68814 & 0.279 \\
\hline
\end{tabular}

Table 9. Hypotheses: Service Quality dimensions and Performance

\begin{tabular}{clcccc}
\hline Hypothesis & Relationship & r & B & p & Supported \\
\hline $\mathrm{H}_{\mathrm{qm}}$ & Quality Management $\rightarrow$ performance & 0.593 & 0.767 & 0.001 & Yes \\
$\mathrm{H}_{\mathrm{ps}}$ & Patient Service Quality $\rightarrow$ performance & 0.479 & 0.279 & 0.001 & Yes
\end{tabular}

Note: $r=$ Pearson Correlation, $\beta=$ regression coefficient, $p$ level of significance at $p<0.001$

In the measurement of service quality management and performance, 150 indicator variables were used from the two constructs. The quality management dimensions $(\beta=0.767)$ and patient service quality $(\beta=0.279)$ strengthened the relationship on performance. The hypotheses $\mathrm{H}_{\mathrm{qm}}$ and $\mathrm{H}_{\mathrm{ps}}$ were supported and statically significant $(\mathrm{P}<0.01)$. The Patient Service Quality model explained the variance was smaller than the model MBNQA. This indicates that the MBNQA criteria had high explanatory power in service quality management and performance of healthcare organizations. The study aligned the internal service quality and external service quality to obtain the holistic view of service quality management and performance in healthcare organizations from the perspective of internal and external customer (Figure 4).

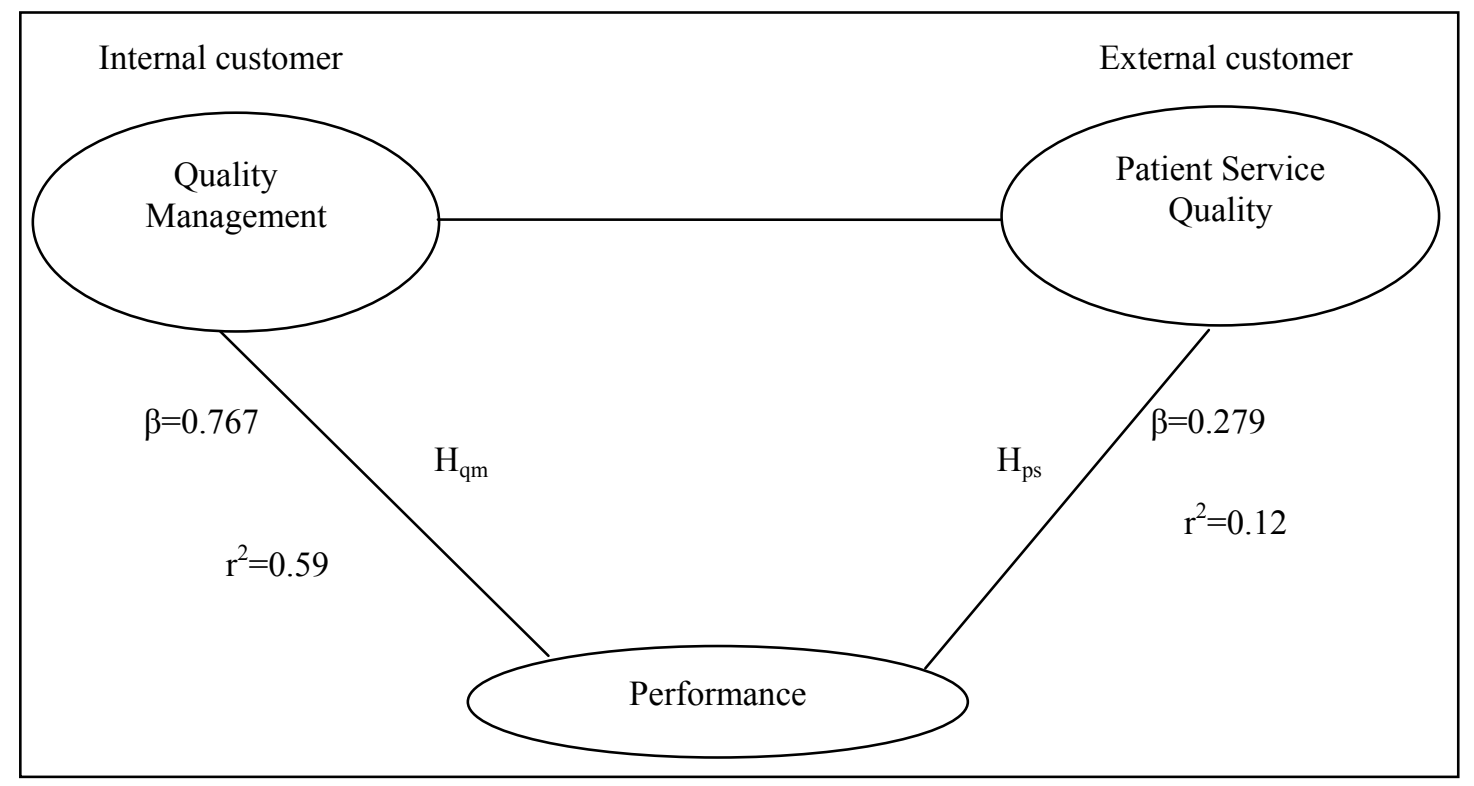

Figure 4. Model of Service Quality management and Performance in Healthcare organizations

\section{Limitation and Directions for Future Study}

The study was limited to selected healthcare organizations of Southern India. The results pertain to medical college hospitals and findings are not generalizable to all types of healthcare organizations. The theoretical model can be further examined in other service organizations including education, bank, insurance, hotel etc. Additional research is needed to extend our understanding of the constructs used in this research, by using different ways to investigate them. Future research is to explore the role of 
leadership; strategic planning; customer focus; measurement, analysis, and knowledge management; workforce focus; and process management separately or in combination in various service settings may be considered.

\section{Conclusions}

The theoretical model examined the influence of quality management dimensions and patient service quality dimensions on performance. The MBNQA dimensions were found to be very useful in evaluation of service quality management and performance in healthcare organizations. The study identified that the healthcare organization had silver line performance based on MBNQA criteria. This research work aligned the internal service quality and external service quality to obtain the holistic view of service quality management and performance in healthcare organizations. The core of MBNQA is about quality and the appearance of MBNQA criteria has changed since inception from quality concept to organizational excellence. Although Quality Council of India (QCI) and Confederation of Indian Industry (CII) began their quality journeys in the 1990s there is a lot to achieve in the Indian context. MBNQA criteria uncovered here will establish a path to meet that challenge. This study could guide the management to align consumers and employees behavior towards the practice of active management of service quality and performance, to set a benchmarking themselves and with other healthcare organizations and most importantly, linking together the, elements of strategy, particularly the workforce focus, the patient focus and performance outcomes in powerful and sensible ways. This study can be the starting point of regular strategic planning process within the healthcare organization and ensure continuous quality improvement. The future research work can be focused on to identify core sets of quality measures for standardized reporting by all sectors of the healthcare industry, an establishment of framework for quality measurement and reporting. Overall, this study is a motivation to healthcare organizations to embrace MBNQA criteria and improve their performance with respect to service quality.

\section{Appendix I: List of items for measuring performance excellence in healthcare organization. Leadership}

We have a tradition of visionary and innovative leadership

Our actions create a sustainable, high-performing healthcare organization

There is high degree of acceptance of responsibility for quality by department heads

Degree to which top management considers quality improvement as a way to increase profits

We stay true to the core values while changing and improving of quality

We place patients first

We use performance feedback to improve our quality care

We create an environment for empowerment, agility and learning

We have cordial relationship and collaboration with administrative /operational level

We are committed to recognize and reward the contribution by the members of workforce

We have a code of conduct for workforce in the organization

We actively participate in social responsibilities

We integrate social responsibility into performance improvements efforts

Our leadership focused on the well-being of the community

We are prepared for community emergencies

Leadership collaborates with others to solve basic community problems

We dedicate fiscal and human resources to improve the community's quality of life

We provide services for those who cannot pay

\section{Strategic Planning}

We have a comprehensive short- term and long -term goals

Our short- term and long -term goals are aligned with customer's needs and healthcare market expectations

Our short- term and long -term goals are well associated with competitive environment change

Short- term and long -term goals are related with strengths and weakness

We have set strategic objectives for our healthcare organization

Business partners support our strategic plan

Strategic decisions are evaluated with objective measures

Our strategic objective include reducing waste

We have deadline for achieving our strategic objectives

Long -term strategies include projections of our services as compared to other healthcare organization

\section{Customer Focus}

We understand who is our customer

We have a customer-oriented vision that is clearly defined and communicated to us

We have a customer-oriented culture that embeds customer satisfaction throughout Organizational practices

Our work unit actively seeks feedback from customers regarding our services 
Important changes in the products, policies, procedures, new activities etc. are communicated clearly to the work group We deal with our customer with high integrity and fairness

We Listen and learn from the customers

We act to the customer requirements

We have fostered the satisfaction and loyalty of the customers

The requirement of the customers are effectively disseminated through out the hospital

We have effective management process for solving customer's complaints

We have aggregated and analyzed the customer's complaints for the opportunities of improvement

We systemically and regularly measure the extent of customer satisfaction

We compare the customer satisfaction information with competitors and similar other providers

\section{Measurement, Analysis and Knowledge Management}

We regularly check the hardware to make sure they are reliable and meet current healthcare needs

We regularly check the software to make sure they are reliable and meet current healthcare needs

We have a comprehensive system to align measures of daily operations and hospital performance

Inter organization coordination is achieved using electronic links

Our information systems are standardized across the departments

Our systems support front line employees

Our performance analysis is aligned with senior leader's strategic planning

We communicate the analysis results to work in team/ group at the functional level operations

Our data analysis shows improvement in cycle times (reducing length of stay)

We ensure the needed data and information available to the staff, suppliers, and customers, as appropriate

We regularly communicate and share the knowledge/ skill through seminar or on site information

We ensure the data and information match current healthcare needs

We ensure the data and information integrity and accuracy

We effectively use comparative data and information to analyze the performance

We use the results to act as the basis for improvement and benchmarking

Patient preferences are analyzed when design new and revised patient services

We have a comprehensive system to gather and integrate information for decisions making

\section{Workforce Focus}

Sufficient effort is made to get the opinions and thinking of people who work here

We are free to discuss work-related issues with my immediate manager/supervisor

We feel comfortable to communicating openly with senior management when the need arose

We resolve complaints on first contact whenever possible and take the steps necessary to solve customer problems.

We avoid transferring the customer from one employee to another to get a problem resolved

We have given the authority to fix problems on the spot

We are satisfied with our involvement in decisions that affect our work

We have access to the information what we need to serve our customer

Our hospital does an effective job of developing employees at all levels

New employees receive adequate training for their jobs

We are satisfied with the training that we receive for our present job

We have sufficient information about training and educational opportunities available at our Hospital

The training made available to me helps me do a better job

We are given the opportunity to improve our skills in our Hospital

We organize work and job flexibility

We work together by cooperation and team work

We have a well developed staff performance management system to reward high performance

We have comprehensive system to motivate staff, and help them attain career development

The process of recruitment, hiring and retaining of new staff are well evaluated by human resource department

Communication and follow-through on promises was bad

There are a regular meetings and workshops

We have conducive working environment

Process Management

We have established effective service delivery system

We obtain feedback on support services from patients

We incorporate changing customer and market requirement and new technology into related process

We address the quality of healthcare in design processes

We ensure efficiency and effectiveness in service process 
We have customer participation in the service process

We have a standardized and documented operating procedure to support daily operations

Support services from hospital were sufficient to manage the practice

We have effective methods to assess performance to improve our service delivery process.

We have given the clarity of work or process instructions

The way jobs and work flow are organized in my work unit is effective

We have enough time to get the job done well

Job makes good use of my skills and abilities

We have given the appropriate authority needed to our job

We have sufficient staff to handle the normal workload in our work unit at the required level of service

We use IT-enabled transaction in our service delivery

\section{Performance Outcomes (Results)}

The number of admissions is increased in recent years

Revisit rate to the emergency department is increased

Patient length of stay is decreased

Customer satisfaction has shown improvement

The waiting line has reduced

The number of customer complaints has decreased

Our financial results have been improving

Total income increased

Total expenditure decreased

The number of employees participating in quality activities has increased

Employee turnover decreased

Employee's satisfaction increased

Number of surgeries increased

Occupancy rate increased

The number of healthcare products increased

Employees know the vision, mission and business objectives

There is strong impact of staff involvement in quality management and improvement activities

Social responsibilities schemes increased

\section{Appendix II: List of items for measuring patient service quality in healthcare organization Doctors quality of care}

Doctors are friendly

Doctor answer your queries satisfactorily

Doctors are always helpful and supportive

Doctors always listen to what you had to say

They explain clearly about the treatment

They also treat your families and friends nicely

They communicate with nurses very well

They communicate with supportive staff very well

They are always ready to clear your doubts

They are always available on time

\section{Nursing quality of care}

Nurses give sufficient care to you

Nurses are always helpful and supportive

They are always ready to listen to what you had to say

Nurses are friendly

They reply your queries very satisfactorily

They treat your relatives and friends very nicely

They explain clearly about the technicality of the treatment

They communicate with supportive staff very well

They communicate with doctors very well

They are available at the time of need

Operative quality of care

Admission process is simple 
Billing system is satisfactory

Proper queue management is followed

Internal atmospheric environment is attractive

Blood bank service is good

Laboratory facilities are very good

Surgery operations schedule is well planned

Bed sheets /linens are changed daily

There is always conducive interaction with the frontline staff

Housekeeping services and canteen facilities are good

Overall service Quality

Your expectations are fully met with regard to doctors

Your expectations are fully met with regard to Nurses

Overall administration is good

Overall cleanliness maintained

You are very satisfied with the hospital

\section{Acknowledgements}

The authors are grateful for the helpful comments from anonymous reviewers, Editor and Co Editors. Their insightful comments and suggestions are benefited us improve the quality this manuscript.

\section{References}

Andersen,H.V., Lawrie,G. and Savic,N(2004). Effective quality management trough third generation balanced score card, International Journal of productivity and performance management, 53,634-645.

Anderson, J.C., Rungtusanatham, M., Schroeder, R.G. and Devaraj, S. (1995). A path analytic model of a theory of quality management underlying the Deming management method: preliminary empirical findings. Decision Sciences, 26, 637-658.

Brown,T.M., Cueto, M. and Fee,E.(2006), The world health organization and transition from "international" to "global" pubic health, American Journal of Public health, 96, 62-72.

Chow-Chua, C. and Goh, M., (2000), Quality improvement in the Healthcare Industry: Some evidence from Singapore, International Journal of Health Care Quality Assurance, 13(5):223-229.

Comrey, A. L., \&Lee, H. B. (1973), A First Course in Factor Analysis, New York: Academic Press.

Cooper, D. R. and Schindler, P. S. (2001). Business Research Methods, 7th Edition New York, NY: McGraw Hill.

Curkovic, S., Vickery, S. and Droge, C. (2000). Quality-related action programs: their impact on quality performance and firm performance. Decision Sciences, 31, 885-905.

D.M.Pestonjee,Kajal H.Sharma and Sonal Patel(2005), "Image and Effectiveness of Hospital: An HR Analysis", Journal of Health Management, Vol.7.No.1, Sage Publication.

Deming, W.E. (1982), Quality, Productivity and Competitive Position, Cambridge: MIT Center for Advanced Engineering.

Donabedian,A.,(1980),Explorations in Quality Assessment and Monitoring, Health Administration, Vol. 1, No.1, pp.77-128.

Dow, D., Samson, D. and Ford, S. (1999). Exploding the myth: do all quality management practices contribute to superior quality performance? Production and Operations Management, 8, 1-27.

D'Souza Sunil and Sequeira A.H. (2008), Revolutionizing healthcare services-Strategic alternatives, Journal of management (Tatva), Vol.5, No.1, ISSN 0973-0974.

D'Souza Sunil and Sequeira A.H. (2010 b). MBNQA criteria and Performance measurement: review, critique, and research agenda, PES Business review, Vol.5, No.2, ISSN 0973-919 X.

D'Souza Sunil and Sequeira A.H. (2011). Information Systems and Quality Management in Healthcare Organization:An Empirical Study, Journal of Technology Management for Growing Economies, Vol 2, Issue 1, fall April 2011.

D'Souza Sunil and Sequeira A.H. (2010a). A critical analysis of service quality and performance through Malcolm Baldrige national quality healthcare criteria: benefits and research directions, International conference on Healthcare Market and Emerging consumers-Innovation, Efficiency and Effectiveness (CD -ROM), Manipal Institute of Management, Manipal University.

Flynn, B.B., Schroeder, R.G. and Sakakibara, S. (1995). The impact of quality management practices on performance and competitive advantage. Decision Sciences, 26, 659-691.

Giffith,J.R., Alexander ,J.A. and Jelinek,R.C.(2002).Measuring comparative hospital performance, Journal of healthcare management, 47, 47-57.

Groene,O., Skau,J.K.H. and Frolich, A.(2008). An International review of projects on hospital performance assessment, International Journal for quality in healthcare, 20,162-171. 
Hibbard,J.H.Stockard,J. and Tusler,M.(2005). Hospital performance reports: impact on quality, market share, and reputation, Health Affairs, 24, 1150-1160.

Institute of Medicine (2001). Crossing the Quality Chasm: A New Health System for 21st Century, Washington,DC: Institute of Medicine of the National Academies, Committee on Quality of Healthcare in America.

Juran, J.M. (1988). On Planning for Quality, London: Collier Macmillan.

Kaynak, H. (2003). The relationship between total quality management practices and their effects on firm performance. Journal of Operations Management, 21, 405-435.

Kaynak, H. and Hartley, J.L. (2005). Exploring quality management practices and high tech firm performance. Journal of High Technology Management Research, 16, 255-272.

Keng,B.O.,Nooh,A.B.,Veeri,A.,Lorraine,V., and Loke,A.K.Y(2007).Does TQM influence employees job satisfaction : An Empirical case analysis?, Internal Journal of quality and reliability management,Vol.24(1),p.62-77.

Kunal Banerji, David E. Gundersen \& Ravi S. Behara (2005). Quality Management Practices in Indian Service Firms, Total Quality Management, Vol. 16, No. 3, 321-330.

Lakhal, L., Pasin, F., and Limam,M.(2006).Quality management practices and their impact on performance, International journal quality and reliability management, 17,876-898.

Li.L.(1997). Relationship between Determinants of Hospital Quality Management and Service Quality Performance- a Path Analytic Model, Omega, Vol.25, No.3, pp.535-45.

Lin,C.,Chow, W.S Madu, C.N., Kuei,C.H. and Yu,P.P.(2005). A structural equation model of supply chain quality management and organizational performance. International journal of production economics,96,355-365.

M. Pilani Natha Raja,S.G.Deshmukh and Subhash Wadhwa(2007).Quality Award Dimensions: a Strategic Instrument for Measuring Health Service Quality, International Journal of Healthcare Quality Assurance, Vol.20, No.5, p.363-378.

Micro Soft Corporation (2008). Map Point in the Healthcare Industry: Today's Challenges in the Healthcare Industry.

Available at www.microsoft.com/mappoint/industries/healthcare/hea_challenges.mspx

Monge, C.A.M.,Rao,S.S.,Gonzalez, M.E. and Sohal, A.S.(2006).Performance measurement of AMT: A cross -regional study, Benchmarking: An International Journal, 13,135-146.

Nunnally,J.C.(1978). Psychometric Theory, New York: McGraw-Hill.

Overtveit,J and Al Seouri,A(2006).Hospital quality management system in low income Arabic country: an evaluation, International Journal of healthcare quality assurance, 19,519-32.

Ovretveit.J.(2000), The Norwegian Approach to Integrated Quality Development, HealthCare Review online: Experience in practice, Vol.2 No.1.

Ozden,B., and Birsen,K.(2006),An Analytical network process -based framework for successful total quality management(TQM); An assessment of Turkish manufacturing Industry readiness, International Journal of production economics, Vol.105,p.79-96.

Powell, T.C. (1995). Total quality management as competitive advantage: a review and empirical study, Journal of Strategic Management 16, 15-37.

Prajogo,D.I., and Sohal, A.S.(2004). The multidimensionality of TQM practices in determining quality and innovation performance: An empirical examination. Technovation, 24,443-453.

Rahman, S. and Bullock, P. (2005). Soft TQM, hard TQM, and organizational performance relationships: an empirical investigation. Omega, 33, 73- 83.

Rahman, S.(2001). A comparative study of TQM practice and Organizational performance of SMEs with and without ISO 9000 certification, International Journal of Quality \& Reliability Management, 18, 35-49.

Ruiz,U.and Simon,J.(2004). Quality management in healthcare: a 20 -year journey, International Journal of healthcare quality assurance, 17,323-333.

Samson, D. and Terziovski, M. (1999). The relationship between total quality management practices and operational performance, Journal of Operations Management, 17, 393-409.

Saraph, G.V.P., Benson, G. \& Schroeder, R.G. (1989). An instrument for measuring the critical factors of quality management, Decision Sciences, 20, pp. 810-829.

Shaw, C. (2003), How can hospital performances measured and monitored, Health Evidence network synthesis report on hospital performance".

Available at, http://www.euro.who.int./document/e 8295.pdf. WHO, Copenhagen.

Sila, I. and Ebrahimpour, M. (2005), Critical linkages among TQM factors and business results. International Journal of Operations \& Production Management, 25, 1123-1155.

Sila,I (2007).Examining the effects of contextual factors on TQM and performance thorough the lens of organizational theories: An empirical study, Journal of operational management, 25, 83-109.

Terziovski, M., Power, D. and Sohal, A. (2003). The longitudinal effects of the ISO 9000 certification process on business performance, European Journal of Operational Research, 146, 580-595.

US Department of Commerce National Institute of Standards and Technology (2003). Malcolm Baldrige National Quality Award Criteria for Performance Excellence 2003, US DoCNBS: Washington, DC. 
US Department of Commerce National Institute of Standards and Technology (2008). Malcolm Baldrige National Quality Award Criteria for Performance Excellence 2008, US DoCNBS: Washington, DC.

US Department of Commerce National Institute of Standards and Technology (2011). Malcolm Baldrige National Quality Award Criteria for Performance Excellence 2011, US DoCNBS: Washington, DC.

Willis,C.D.,Stoelwinder.J.U and Cameron,P.A.(2008). Interpreting process in trauma care: Construct validity versus confounding by indication, International Journal of Quality Healthcare, 20,331-338.

Woodward, G., Manuel, D.and Goel.V. (2004), Developing a balanced score card for pubic health, ICES investigative report Toronto:ICES.www.ices.on.ca/file/scorecard_report_final.pdf.

World Healthcare Organization (2009). Maximizing positive synergies between health systems and global health initiatives, http://www.who.int/ health systems/New-approach -leaflet-ENv2-p4p.pdf.

Yang Ching-Chow (2006), Establishment of quality -management system for service Industries, Total Quality Management, vol.17.No.9, 1129-1154.

Yin,R.K(1994). Case study research, Design and Methods, 2nd ed. Sage publications, Beverly, hills, C.A.

\section{Biographical notes}

Sunil Cyprian D'Souza, pursuing his PhD in healthcare management at National Institute of Technology, Karnataka, India. His research interests' area includes services management, strategic marketing, total quality management, and enterprise resource planning. Sunil Cyprian D'Souza is the corresponding author and can be contacted at: sunildsouza31@gmail.com.

Dr. A.H. Sequeira, Professor in the Department of Humanities, Social Sciences and Management, National Institute of Technology Karnataka, India. He holds M.Tech (IITB), PhD and has 30 years of teaching experience and guided three PhD students. His research interests' areas include Marketing Management, Financial Management, Human Resource Management, Education Technology, Management Information Systems, Research Methodology, and Productivity Management. He has published several papers in national and international conferences and journals. E-mail: aloysiushs@gmail.com

Received January 2011

Accepted June 2011

Final acceptance in revised form June 2011 